\title{
Using of clinoptilolite, activated charcoal and rock crystal in water purification technology to enhance the biological value of bread kvass
}

\section{Olha Dulka1, Vitalii Prybylskyi ${ }^{1}$, Svitlana Oliinyk ${ }^{1}$, Anatolii Kuts ${ }^{1}$, Oksana Vitriak ${ }^{2}$}

\author{
1 - National University of Food Technologies, Kyiv, Ukraine \\ 2 - Kyiv National University of Trade and Economics, Kyiv, Ukraine
}

Keywords:

Water

Watertreatment

Wort

Kvass

Vitamin

Article history:

Received 28.08.2018

Received in revised

form 30.11.2018

Accepted 31.05.2019

Corresponding

author:

Olha Dulka

E-mail:

olga.ds210791@

gmail.com

DOI: $10.24263 / 2304-$

974X-2019-8-2-10

\section{Abstract}

Introduction. It has been determined the influence of drinking running water purified by clinoptilolite, rock crystal and activated charcoal on the vitamin content of wort and kvass.

Materials and methods. The kvass made by kvass rye wort fermentation with the help of yeast Saccharomyces cerevisiae MP-10 was analyzed. The dry matter content was determined by the areometric method, the content of vitamins by the ability of test-cultures to grow in the presence of certain vitamins. Thiamine and riboflavin were determined by fluorometric method.

Results and discussion. In the purified water, the total iron content was $0,01 \mathrm{mg} / \mathrm{dm}^{3}$, the total water hardness was 1,1 $\mathrm{mmol} / \mathrm{dm}^{3}$, the permanganate oxidation was $0,5 \mathrm{mg} \mathrm{O} / \mathrm{dm}^{3}$. The fermentation process was similar to both samples. While the total duration of fermentation of the experimental sample was $13 \%$ less, that is due to a decrease in the number of vitamins in the initial wort. The water mineral composition significantly influenced on the content of vitamins in the initial and fermented wort and kvass, in particular, the amount of thiamine and riboflavin in the prototype increased at an average 2.5 times, and the folic acid content at 5 times, that can be explained by the formation in the control sample of water insoluble complexes with bivalent metals. At using model solutions with an index of total water hardness of 5 $\mathrm{mmol} / \mathrm{dm}^{3}$, the thiamine content in the fermented wort decreased by 6,7 times compared to the wort with demineralized water. To ensure high levels of vitamins in the kvass, in particular thiamine, riboflavin and folic acid, process water should have a total hardness no more than $1 \mathrm{mmol} / \mathrm{dm}^{3}$ and contain no iron ions.

Conclusions. The use of purified water provides the increase in the content of vitamins in the kvass and getting the product with their correlation physiologically acceptable to the human body. 


\section{- Food Technology —}

\section{Introduction}

Soft drinks are not essential products, but they play an important role in the metabolism of humans [1-4]. Consumption of beverages should not only compensate for the loss of moisture and salts by the body, but also enrich it with vitally necessary biologically active substances, particularly, vitamins [1, 5-7].

When comparing different groups of soft drinks in terms of therapeutic and preventive and general health effects on the human body, fermented beverages are the most promising. Functional fermented beverages based on plant extracts have become significantly more widely used [10-13].

Bread kvass is one of the most popular fermented soft drinks, which is prepared on the basis of rye raw materials by alcohol fermentation [12-14]. In the process of life, yeast ferments carbohydrates with the formation of the main, secondary and by-products of metabolism, as well as vitamins and other biologically active substances $[13,14]$.

Therefore, the introductions of innovative technologies that increase the biological value of bread kvass, in particular the vitamins content are topical issues of the industry's development.

Water is one of the main components of bread kvass. However, most companies do not carry out additional water treatment as raw materials for kvass production [7, 12].

A promising trend in the food products technology, where water is raw material, is the use of natural minerals, in particular clinoptilolite and rock crystal, as well as active coal at the stage of water treatment $[13,15]$.

The purpose of the work is to study the influence of clinoptilolite, activated charcoal and rock crystal during the watertreatment stage on the vitamins content in the initial and fermented kvass worts and to determine their correlation according to needs of the human body.

\section{Materials and methods}

\section{Purification of water and preparation of model solutions}

Treatment of drinking running water was carried out by clinoptilolite of Sokirnitsky field (Ukraine), activated charcoal and rock crystal in laboratory conditions under certain conditions (Patent 116963 Method of water treatment for the kvass production). Clinoptilolite was used to reduce the hardness of water and removal of heavy metals $[16,17]$. The structure of clinoptilolite is tetrahedron, the vertices of which form eight-membered rings, inside of which there are water molecules («zeolite water»), and alkaline and alkaline earth metals cations. A large number of input windows on the surface has channels, which provide the use of clinoptilolite as a «molecular sieve» with the replacement of cations (the size of the input windows $\left.3,5-4,8 \mathrm{~A}^{\circ}\right)[18,19]$.

Activated charcoal was used to reduce the content of organic impurities and improve the organoleptic parameters of water [13, 20, 21].

Rock crystal was used in order to structure the water, correct the oxidation-reduction potential and remove foreign microflora [6].

In the purified water, the total iron content was $0,01 \mathrm{mg} / \mathrm{dm}^{3}$, the total water hardness was $1.1 \mathrm{mmol} / \mathrm{dm}^{3}$, the permanganate oxidation was $0,5 \mathrm{mg} \mathrm{O} / \mathrm{dm}^{3}$. For control, untreated water with a total iron content of $0,05 \mathrm{mg} / \mathrm{dm}^{3}$, a general hardness of $4,5 \mathrm{mmol} / \mathrm{dm}^{3}$, and a permanganate oxidation of $4,0 \mathrm{mg} \mathrm{O}_{2} / \mathrm{dm}^{3}$ were used. 


\section{- Food Technology —}

For conducting experimental study the optimal parameters of technological water for the kvass production wort was prepared using demineralized water and with a certain amount of hardness salts and iron.

The weight of a model substance was calculated by the formula:

$$
\mathrm{m}_{\mathrm{pM}}=\left(\mathrm{M}_{\mathrm{pM}} \cdot \mathrm{C}_{\mathrm{Mp}} \cdot \mathrm{V}_{\mathrm{мp}}\right) / \mathrm{M}_{\mathrm{pp}}
$$

where $\mathrm{m}_{\mathrm{pm}}$ is the weight of substance, by means of which the quality of technological water was modeled, mg;

$\mathrm{M}_{\mathrm{pM}}$ is the molecular weight of the substance used to prepare model solution, $\mathrm{g} / \mathrm{mol}$;

$\mathrm{C}_{\mathrm{мp}}$ is the concentration of model solution, $\mathrm{mg} / \mathrm{dm}^{3}$;

$\mathrm{V}_{\mathrm{мр}}$ is the volume of the model solution, $\mathrm{dm}^{3}$;

$\mathrm{M}_{\mathrm{pp}}$ is the molecular weight of the soluted substance that needs to be modeled, $\mathrm{g} / \mathrm{mol}$.

\section{Preparation of kvass wort and kvass}

For the cultivation of yeast, the wort was prepared from kvass wort concentrate, sugar syrup and water with the concentration of dry matter 7,0-8,0\%. The wort for preparing kvass was prepared with the concentration of dry matter of 3,4-3,6\%, it was fermented with pure yeast culture of Saccharomyces cerevisiae MP-10 (initial concentration of yeast cells in the wort was $0,6 \mathrm{mln} / \mathrm{cm}^{3}$ ) at a temperature of $34{ }^{\circ} \mathrm{C}$ to reduce the content of dry matter to 0,8 $1,0 \%$. The kvass was prepared by mixing fermented wort separated from the yeast sediment to dry matter content $5,4-5,6 \%$.

There were prepared two samples of kvass wort:

-control sample is wort on untreated water;

-experimental sample is wort on purified water.

\section{Determination of the vitamins content}

The vitamins content was determined by the microbiological method; Thiamine and Riboflavin by fluorometric method; the content of the Thiamine-Catechin complex by the permanganate Leventhal method [16].

As objects of research there were used: drinking water from centralized water supply in Lviv city, activated charcoal Silcarbon, rock crystal, clinoptilolite, kvass wort concentrate, sugar, yeast Saccharomyces cerevisiae MP-10 and finished bread kvass.

\section{Results and discussion}

\section{Influence of water purification on the yeast cultivation process and kvass wort fermentation}

The biological value of kvass is largely due to the presence of vitamins which are growth factors, and the physiological activity of yeast depends on their amount $[3,4,13]$.

The specific growth rate of yeast cells at the yeast cultivation stage is given in Table 1 . 
Specific growth rate of yeast

\begin{tabular}{|c|c|c|}
\hline $\begin{array}{c}\text { Duration of } \\
\text { cultivation, hours }\end{array}$ & \multicolumn{2}{|c|}{ Specific growth rate, hours $\mathbf{~}^{\mathbf{1}}$} \\
\cline { 2 - 3 } & Control & Experiment $^{-}$ \\
\hline 6 & 0,333 & 0,464 \\
\hline 12 & 0,368 & 0,495 \\
\hline 18 & 0,060 & 0,078 \\
\hline 24 & 0,022 & 0,028 \\
\hline
\end{tabular}

A higher specific growth rate of yeast on average of 1,3 times throughout the entire cultivating process was observed using the experimental sample of wort.

The dynamics of reducing the dry matters content at fermentation of the experimental and control samples of wort at a temperature of $34{ }^{\circ} \mathrm{C}$ is shown in Figure 1.

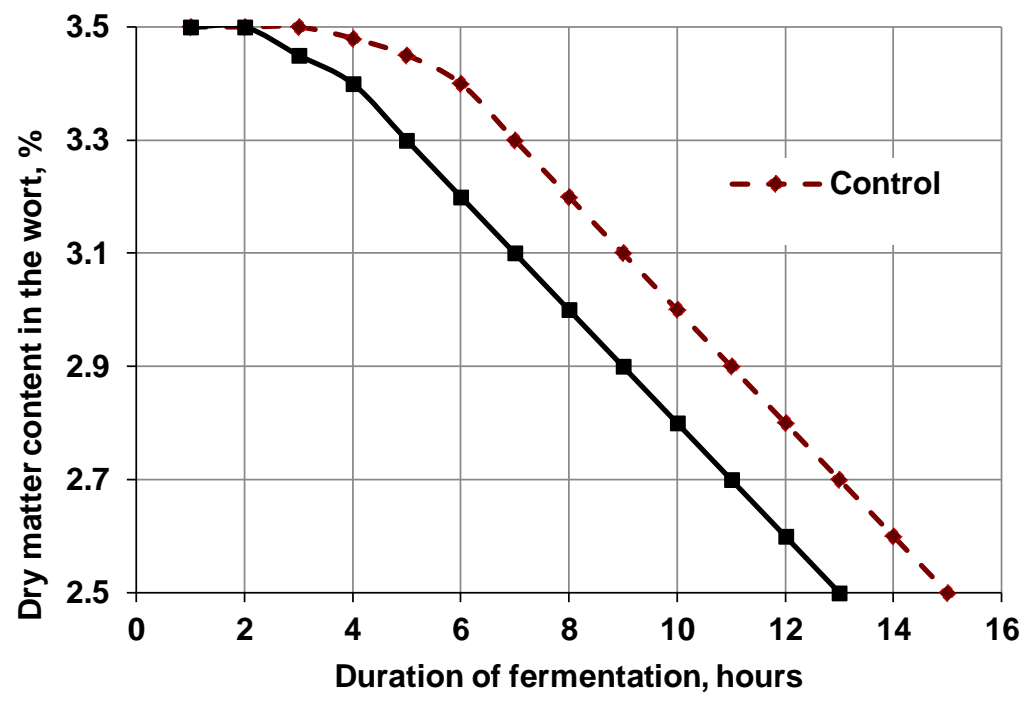

Figure 1. Dynamics of reducing dry matters content at kvass wort fermentation

It was found that the character of fermentation was similar for both samples. However, when using wort on prepared water, the process of intense wort fermentation began already at the second hour, then, for control at the third. In this case, the total fermentation time of the experimental sample was fixed at $13 \%$ less, that is explained by the reduction in the duration of the lag phase of the yeast growth.

The zymase enzymes of yeast are complex substances containing the protein part (apoenzyme) and chemically bound nonprotein (coenzyme). Coenzymes determine the specific activity of the enzyme, take part in its contact with the substrate, and also stabilize apoenzymes. Coenzyme has two functional areas, one of which is responsible for the association with apoenzyme, and the other takes direct part in the catalytic process [22]. It is known that coenzymes contain vitamins which are irreplaceable factors that provide the required rate of biochemical and physiological processes in the yeast cell. The role of vitamins as coenzymes in chemistry of alcohol fermentation is presented in Figure 2 [23]. 


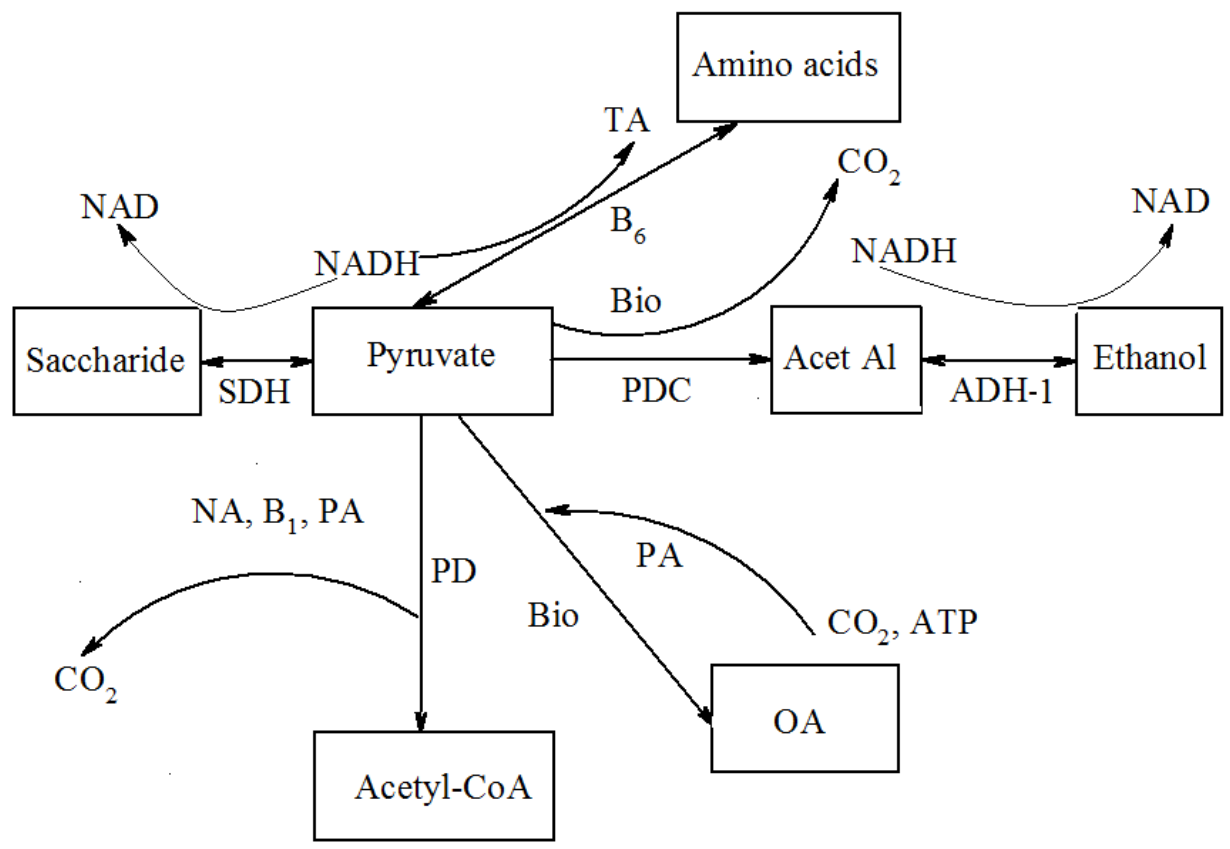

Figure 2. Sugar metabolism in the yeast cell:

PDC - pyruvate decarboxylase;

TA - transaminase;

PC - pyruvate carboxylase;

$\mathrm{PD}$ - pyruvate dehydrogenase;

SDH - saccharide dehydrogenase;

ADH-1 - alcohol dehydrogenase;
$\mathrm{B}_{1}$ - thiamine;

$\mathrm{B}_{6}-$ pyridoxine;

NA - nicotinic acid;

Bio - biotin;

$\mathrm{PA}$ - pantothenic acid;

$\mathrm{OA}$ - oxalacetate;

Acet $\mathrm{Al}$ - acetaldehyde.

\section{Water influence on the vitamin content of the initial and fermented kvass wort}

In determining the vitamin content of the initial wort and fermented wort, the increase in their content after fermentation was determined, this is due to the ability of the yeast to synthesize vitamins [24]. In all samples of fermented wort, the increase in the content of group B vitamins was observed. Table 2 shows the dependence of the vitamin content of the initial and fermented worts on the water used.

Table 2

Content of vitamins in the initial and fermented worts

\begin{tabular}{|l|c|c|c|c|}
\hline \multirow{2}{*}{$\begin{array}{c}\text { Vitamins content, } \boldsymbol{\mu g} \\
\text { in 100 g of dry matter }\end{array}$} & \multicolumn{2}{|c|}{ Initial wort } & \multicolumn{2}{c|}{ Fermented wort } \\
\cline { 2 - 5 } & Control & Experiment & Control & Experiment \\
\hline Thiamin $\left(\mathrm{B}_{1}\right)$ & 7 & 16 & 36 & 103 \\
\hline Riboflavin $\left(\mathrm{B}_{2}\right)$ & 5 & 11 & 51 & 122 \\
\hline Niacin $\left(\mathrm{B}_{5}\right)$ & 480 & 560 & 980 & 1170 \\
\hline Pyridoxine $\left(\mathrm{B}_{6}\right)$ & 5 & 12 & 19 & 33 \\
\hline Biotin $(\mathrm{H})$ & 0,45 & 0,56 & 0,76 & 1,2 \\
\hline Folic acid & 2 & 11 & 6 & 28 \\
\hline
\end{tabular}


It was defined that the mineral composition of water significantly influenced the vitamins content in the initial and fermentation wort, in particular the content of thiamine and riboflavin in experimental samples increased at an average of 2,5 times. The highest content was observed for niacin. The increasing vitamin content in the kvass is explainable with their initial raw material content and their creation in the process of yeast life activity.

A significant role in the life activity of yeast cells is played by biotin, which is involved in various metabolic processes, particularly in carboxylation of pyruvate, pyridine nucleotide synthesis, nucleic acids, proteins, polysaccharides, fat acids synthesis, the formation of purine and pyrimidine bases [23, 25]. It is determined the increase in the content of biotin in the fermented wort for experimental and control samples, respectively, at 37 and $20 \%$.

Folic acid is necessary for the formation of new cells and does not have coenzyme properties, but when converted to tetrahydrofolic acid, it participates in DNA replication, amino acid synthesis, in particular methionine and serine, as well as the formation of nucleic acids, pyrimidines and purines. Tetrahydrofolic acid also takes part in the transfer of the methyl, methylene and carbonyl groups, that promotes the activation of enzymes, which take part in fixing the formaldehyde and formic acid residues and their catalytic transformations $[23,25]$.

The Figure 3 shows the interaction of folic acid with ions of bivalent metals [25].<smiles>[R]c1cnc2nc(N)nc(O)c2n1</smiles><smiles>[R]c1cnc2nc(N)nc(O[M]Oc3nc(N)nc4ncc([R])nc34)c2n1</smiles>

Figure 3. Interaction of folic acid with ions of bivalent metals

In the experimental samples of the initial and fermented worts, an increase in the content of folic acid was observed, respectively, at 5,5 and 4,6 times, that can be explained by the formation in the control of water-insoluble complexes with bivalent metals $\left(\mathrm{Cu}^{2+}, \mathrm{Fe}^{2+}, \mathrm{Co}^{2+}\right.$, etc.) by the equation given in Figure 3.

\section{Influence of hardness salts and iron ions on Thiamine and Riboflavin content}

One of the most important vitamins for a human body is thiamine, which is formed by condensation of the pyrimidine and thiazole nucleuses $[26,27]$. The content of thiamine in drinks substantially depends on the calcium and magnesium salts, which reduce its solubility. Therefore, reducing the hardness of technological water allows increase the amount of thiamine, and therefore increase the biological value of kvass. In addition, thiamine positively effects the process of fermentation of the wort, increasing its speed. Coenzyme thiamine diphosphate is used by yeast in the reactions of the conversion of pyruvic acid to acetaldehyde, which is a determining factor in alcohol fermentation [28]. Thiamine also regulates the condensation of acetone and the formation of butanediol-2,3, that effects the taste and aroma properties of kvass [29]. 
Riboflavin is not the factor in the growth of yeast, but it participates in oxidativereduction reactions under anaerobic conditions [23, 25]. Yeast synthesizes this vitamin in significant quantities. At the same time, its content in kvass depends on the concentration of iron ions, which move into wort both with concentrate kvass wort (CKW) and with water.

The influence of hardness salts and iron ions on Thiamine and Riboflavin contents in fermented wort is shown in Figure 4 and 5.

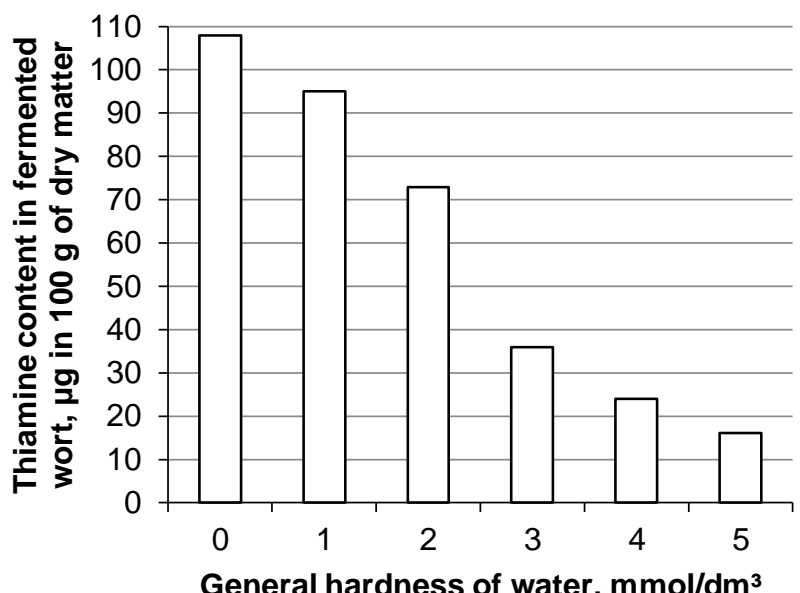

Figure 4. Influence of hardness salts on Thiamine content in fermented wort

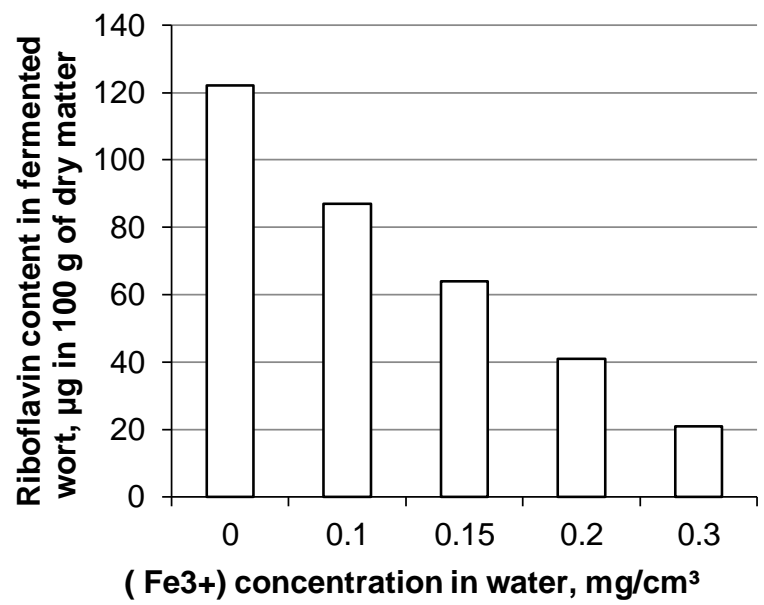

Figure 5. Influence of $\mathrm{Fe}^{3+}$ ions on Riboflavin content in the fermented wort

It was defined that when using model solutions with the index of general hardness at 5 $\mathrm{mmol} / \mathrm{dm}^{3}$, the Thiamine content in the fermented wort decreased by 6,7 times compared with the wort in demineralized water. The water hardness of $1 \mathrm{mmol} / \mathrm{dm}^{3}$ the Thiamine content decreased only at $12 \%$, that is explained by the interaction of Thiamine with calcium and magnesium salts. 
It was established that with increasing concentration of iron ions in water up to 0,3 $\mathrm{mg} / \mathrm{cm}^{3}$, the content of riboflavin in the fermented wort decreased 6 times.

These data observe Calcium, Magnesium and Ferrum ions have the significant influence on the Thiamine and Riboflavin content in the fermented wort. While it is probable, insoluble in water complexes with iron ions are formed.

Thus it has been established that in order to ensure high content of vitamins in kvass, particularly Thiamine, Riboflavin and Folic acid, technological water should have total hardness of no more than $1 \mathrm{mmol} / \mathrm{dm}^{3}$ and should not contain iron ions.

\section{Assessment of the biological value of kvass}

In order to estimate the biological value of kvass in accordance with the requirements of FAO/WHO, an average daily maintenance of vitamins at a consumption of $0,5 \mathrm{dm}^{3}$ of beverages has been calculated. Profiles of the vitamins content of the control and experimental samples of kvass are shown in Figure 6.

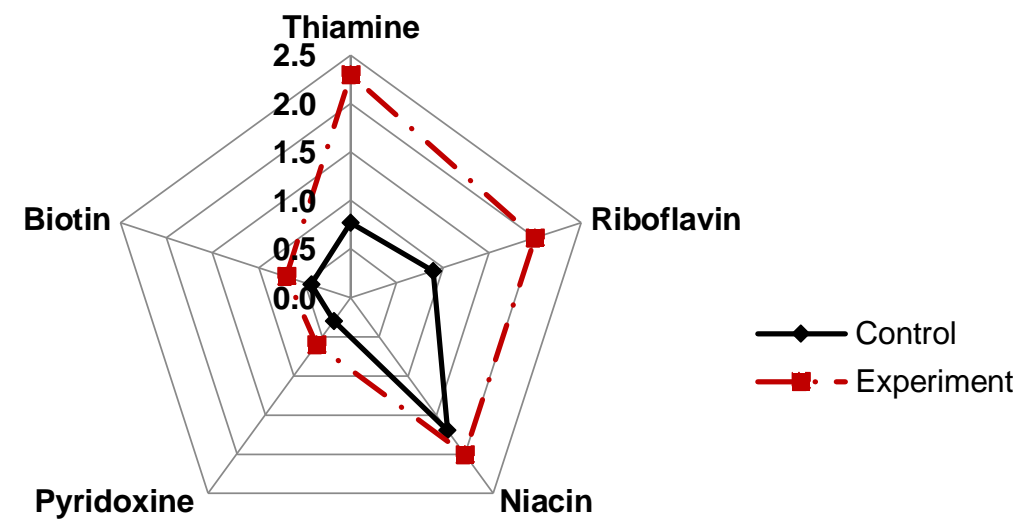

Figure 6. Profile of daily maintenance of vitamins at consumption of $0.5 \mathrm{dm}^{3} \mathrm{kvass}$

It was defined that when using kvass $0,5 \mathrm{dm}^{3}$, the daily requirement for vitamins of group B and niacin is provided by $0,5-2,4 \%$, which is acceptable, since soft drinks are not the main component of vitamins in the human body. From the investigated vitamins, the most consistent with the daily needs are thiamine, riboflavin and niacin. With the use of prepared water the provision human body with these vitamins increases at an average of 2 times (respectively 3, 2,5 and 1,6 times). This can be explained by their taking part in biosynthetic processes of yeast cells.

As you know, a human ration should contain a variety of foods. In this case, the main thing is not the quantitative content of biologically active substances, but their adequacy in accordance with the needs of the human body [26, 27]. The ratio of vitamins in the control and experimental samples in accordance with the physiological needs of the human body is given in Table 3; where for 1 standard unit the established requirements of the daily requirement of vitamins are adopted, and the value of experiment and control is the ratio of their respective content in beverages to the norm. Proximity to 1 standard unit indicates that the content of this vitamin is more in line with $\mathrm{FAO} / \mathrm{WHO}$ requirements. 
Ratio daily providing with vitamins

\begin{tabular}{|c|c|c|c|c|c|}
\hline \multirow{2}{*}{ Name } & \multicolumn{5}{|c|}{ The ratio of vitamins, standard unit } \\
\cline { 2 - 6 } & Thiamine & Riboflavin & Niacin & Pyridoxine & Biotin \\
\hline Control & 0,155 & 0,179 & 0,343 & 0,059 & 0,001 \\
\hline Experiment & 0,444 & 0,427 & 0,410 & 0,103 & 0,002 \\
\hline
\end{tabular}

It was found that the experimental sample compared to control ones most meets determined requirements for Thiamine, Riboflavin, Niacin, Pyridoxine and Biotin, respectively, 2,$9 ; 2,4 ; 1,2 ; 1,8 ; 2.0$ times.

So, kvass is prepared using the purified water by the proposed method and has the increased biological value.

\section{Conclusion}

It has been established that the use of clinoptilolite, rock crystal and activated charcoal during water purification in bread kvass technology provides an increase in the content of vitamins in the initial and fermented wort and the getting of the finished product with the physiological needs acceptable for the human body with the ratio of thiamine, riboflavin, niacin, pyridoxine and biotin.

\section{References}

1. Ball G.F.M. (2004), Vitamins Their Role in the Human Body, Consultant, London.

2. Rosenberg I.H. (2007), Challenges and opportunities in the translation of the science of vitamins, Nutr.

3. Karpenko P.O. (2000), Problemyi pitaniya i zdorovya. Biologicheski aktivnyie dobavki i bioproduktyi, Nora-print, Kyiv.

4. Tsypriiana V.I. (1999), Hihiiena kharchuvannia z osnovamy nutrytsiolohii, Zdorovia, Kyiv.

5. Dudenko N.V., Pavlotskaia L.F., Evlash V.V. (2007), Pischevaya, biologicheskaya tsennost $i$ bezopasnost syirya i produktov ih pererabotki, Kyiv.

6. Smoliar V.I. (2013), Formula ratsionalnoho kharchuvannia, Problemy kharchuvannia, 1, pp. 342-353

7. Pokrovskyi A.A. (1986), Беседы о питании, Экономика, Москва.

8. Mazaraki A.A., Peresichnyi M.I., Kravchenko M.F. (2012), Tekhnolohiia kharchovykh produktiv funktsionalnoho pryznachennia, Kyiv.

9. Volgarev M.N. (2000), O normah fiziologicheskih potrebnostey cheloveka v pischevyih veschestvah i energii: retrospektivnyiy analiz i perspektivyi razvitiya, Voprosyi pitaniya, 4 pp. 3-7.

10. Butenko L.M., Slobodianiuk N.M., Androshchuk O.S. (2013), Vplyv nauky pro kharchuvannia na tekhnolohiiu yakisnykh ta bezpechnykh produktiv, Khlebopekarskoe y kondyterskoe delo, 5, pp. 24-25. 
11. Gernet M.V., Gribkova I.N., Kobelev K.V., Lazareva I.V., Hashukaeva B.R. (2016), Razrabotka tehnologii funktsionalnyih napitkov brozheniya $\mathrm{s}$ ispolzovaniem chaya, Pivo i napitki, 1, pp. 30-34.

12. Shatnyuk L.N., Antipova O.V. (2013), O tendentsiyah v oblasti zdorovogo pitaniya, Konditerskoe proizvodstvo, 3, pp.22-23.

13. Ivanov S.V., Domaretskyi V.A., Prybylskyi V.L. (2012), Innovatsiini tekhnolohii produktiv brodinnia $i$ vynorobstva, Kyiv.

14. Prybylskyi V.L., Romanova Z.M., Sydor V.M. (2014), Tekhnolohiia bezalkoholnykh napoiv, Kyiv.

15. Cherevko O., Holovko O. (2006) Funktsionalni kharchovi produkty, Kharchova $i$ pererobna promyslovist, 6, pp.16-23.

16. Koroliuk T.A., Usatiuk S.I., Kostinova T.A., Filipchenko I.M. (2017), Metodyka kontroliu kharchovykh produktiv, Kyiv.

17. Tarasevych Yu. B., Poliakov V. Ye., Pencho V. Zh (1991), Ionoobminni vlastyvosti i osoblyvosti budovy klynoptylolita riznykh rodovyshch, Khimiia $i$ tekhnolohiia vody, 13(2), pp. 132-140.

18. Inglezakis V.J., Doula M.K., Aggelatou V. A., Zorpas A.A. (2010), Removal of iron and manganese from underground water by use of natural minerals in batch mode treatment, Water Treat, 18, pp. 341-346.

19. Doula M.K. (2006), Removal of $\mathrm{Mn}^{2+}$ Ions from Drinking Water Using Clinoptilolite and Clinoptilolite-Fe Oxide System, Water Research, 40(17), pp. 3167-3176

20. Du J., J.J.,Cullen, Buettner G.R. (2012), Ascorbicacid: chemistry, biology and the treatment of cancer, Biochim Biophys Acta, 1826(20), pp. 443-457.

21. Rao A.V., Rao L.G. (2007), Carotenoids and human health, Pharmacological Research, 55, pp. 207-216.

22. Berry D. R., Russell I.A., Stewart G. G. (2011), Yeast biotechnology, Springer.

23. Berg J., Tymoczko J., Stryer L. (2002), Biochemistry, Freeman, New York.

24. Alfenore S., Molina-Jouve C., Guillouet S. (2002), Improving ethanol production and viability of Saccharomyces cerevisiae by a vitamin feeding strategy during fedbatch process, Microbiol Biotechnol, 60, pp. 67-72.

25. Techenko A. P., Shcherbakova M. A. (2008), Effect of Vitamin Concentration on the Synthesis of Lactate, Ethanol, Pyruvate, and Ethyl Acetate in Cells of the Yeast Dipodascus magnusii, Microbiology, 77, pp. 430-435.

26. Clayton P.T. (2006), B(6)-responsive disorders: A model of vitamin dependency, J. Inherit, 29(2-3), pp. 317-326.

27. Kamchatnov P.B. (2014), Vitamins in neurological clinical practice, Nevrol Psikhiatr, 114(9), pp. 105-111.

28. Jorgensen H. (2008), Effect of Nutrients on Fermentation of Pretreated Wheat Straw at very High Dry Matter Content by Saccharomyces cerevisiae, Humana Press, (8), pp. 44-57.

29. Ilchenko A.P., Shcherbakova M.A. (2008), Effect of Vitamin Concentration on the Synthesis of Lactate, Ethanol, Pyruvate, and Ethyl Acetate in Cells of the Yeast Dipodascus magnusii, Microbiology, (77), pp.430-435. 